\title{
Human T cells express CD25 and Foxp3 upon activation and exhibit effector/memory phenotypes without any regulatory/suppressor function
}

\author{
Maciej Kmieciak ${ }^{1,4}$, Madhu Gowda ${ }^{2,4}$, Laura Graham³,4, Kamar Godder ${ }^{2,4}$, \\ Harry D Bear ${ }^{3,4}$, Francesco M Marincola ${ }^{5,4}$ and Masoud H Manjili*1,4
}

\begin{abstract}
Address: ${ }^{1}$ Department of Microbiology \& Immunology, Virginia Commonwealth University Massey Cancer Center, Richmond, USA, ${ }^{2}$ Department of Pediatrics, Virginia Commonwealth University Massey Cancer Center, Richmond, USA, ${ }^{3}$ Department of Surgery, Virginia Commonwealth University Massey Cancer Center, Richmond, USA, ${ }^{4}$ Department of Pathology, Virginia Commonwealth University Massey Cancer Center, Richmond, USA and ${ }^{5}$ Infectious Disease and Immunogenetics Section (IDIS), Department of Transfusion Medicine, Clinical Center and Center for Human Immunology (CHI), National Institutes of Health, Bethesda, USA

Email: Maciej Kmieciak - mkmieciak@vcu.edu; Madhu Gowda - MSGowda@mcvh-vcu.edu; Laura Graham - lgraham2@mcvh-vcu.edu; Kamar Godder - kgodder@mcvh-vcu.edu; Harry D Bear - hdbear@vcu.edu; Francesco M Marincola - FMarincola@cc.nih.gov;

Masoud H Manjili* - mmanjili@vcu.edu

* Corresponding author
\end{abstract}

Published: 22 October 2009

Journal of Translational Medicine 2009, 7:89 doi:10.1 186/1479-5876-7-89

Received: 22 July 2009

Accepted: 22 October 2009

This article is available from: http://www.translational-medicine.com/content/7///89

(c) 2009 Kmieciak et al; licensee BioMed Central Ltd.

This is an Open Access article distributed under the terms of the Creative Commons Attribution License (http://creativecommons.org/licenses/by/2.0), which permits unrestricted use, distribution, and reproduction in any medium, provided the original work is properly cited.

\begin{abstract}
Background: Foxp3 has been suggested to be a standard marker for murine Tregs whereas its role as marker for human Tregs is controversial. While some reports have shown that human Foxp $3+T$ cells had no regulatory function others have shown their role in the inhibition of $T$ cell proliferation.
\end{abstract}

Methods: $T$ cell activation was performed by means of brayostatin-l/ionomycin (B/I), mixed lymphocyte reaction (MLR), and CD3/CD28 activation. $T$ cell proliferation was performed using $\mathrm{BrdU}$ and CFSE staining. Flow cytometry was performed to determine Foxp3 expression, cell proliferation, viabilities and phenotype analyses of $T$ cells.

Results: Both CD4+ and CD8+ T cells expressed Foxp3 upon activation in vitro. Expression of Foxp3 remained more stable in CD4+CD25+ T cells compared to that in CD8+CD25+ T cells. The CD4+CD25+Foxp3+ T cells expressed CD44 and CD62L, showing their effector and memory phenotypes. Both FoxP3- responder $T$ cells and CD4+FoxP3+ $T$ cells underwent proliferation upon $\mathrm{CD} 3 / \mathrm{CD} 28$ activation.

Conclusion: Expression of Foxp3 does not necessarily convey regulatory function in human CD4+CD25+ T cells. Increased FoxP3 on CD44+ effector and CD44+CD62L+ memory $T$ cells upon stimulation suggest the activation-induced regulation of FoxP3 expression.

\section{Background}

In mice, scurfy mutation in forkhead/winged helix transcription factor gene Foxp3 causes autoimmune lesions including massive lymphoproliferation, diabetes, exfoliative dermatitis, thyroiditis and enteropathy. Such autoimmunity can be cured by a transgene encoding a wild-type 
Foxp3 allele [1]. The expression of Foxp3 in CD4+CD25+ $\mathrm{T}$ cells in wild-type mice and the diminished numbers of these T cells in scurfy and Foxp3-knockout (Foxp3-) mice suggested a role for Foxp3 in the development of regulatory T cells (Tregs) [2]. In addition, Foxp3 has been shown to be a specific marker for murine CD4+ Tregs because activation of non-T regs did not induce Foxp3 expression [2]. Ectopic expression of Foxp3 was shown to be sufficient to activate a program of suppressor function in peripheral murine CD4+ T cells [2].

In humans, the gene encoding Foxp3 was discovered during efforts to understand the genetic basis for a rare $\mathrm{X}$ linked fatal autoimmune disease known as IPEX (immune dysregulation, polyendocrinopathy, enteropathy, X-linked) syndrome [3,4]. However, the role of Foxp3 as a key marker for Tregs in humans remains controversial. Unlike mice, activation of human CD4+ T cells by Tcell receptor (TcR) stimulation resulted in the expression of Foxp3 [5-12]. Most of these studies showed that induction of Foxp3, even in the presence of TGF- $\beta$, did not correlate with suppressive function of CD4+ T cells [6,10-12]. Although it was suggested that lack of suppression during the activation-induced expression of Foxp3 in human $\mathrm{CD} 4+\mathrm{T}$ cells was because of transient expression of Foxp3, the observation still argues against a role for Foxp3 as key regulator of suppression in human CD4+ T cells upon expression. Regardless of the status of Foxp3, many studies considered CD4+CD25 high as Tregs in humans without being able to show their regulatory functions in vivo [13-15]. Most recently, it was reported that maternal alloantigens promoted development of Tregs in the human fetus that could suppress fetal antimaternal immunity. The authors considered CD4+CD25+Foxp3+ T cells as Tregs because of their partial suppressive function in a mixed lymphocyte reaction (MLR) in vitro [16]. These controversial reports prompted us to determine whether induction of Foxp3 expression in human T cells during activation and during MLR may confer regulatory functions. Our studies showed that activation-induced expression of Foxp3 was transient in CD8+CD25+ T cells but it was more stable in $\mathrm{CD} 4+\mathrm{CD} 25+\mathrm{T}$ cells. These Foxp3+ T cells were mainly of effector and memory phenotypes.

\section{Methods}

\section{Blood samples}

PBMC were collected from two healthy donors, and duplicate experiments were performed.

\section{Flow cytometry}

Three-color staining and FACS analyses were performed as previously described by our group [17]. Extracellular staining were performed using anti-human antibodies from Biolegend: PE- and FITC-CD25 (clone BC96), PEand FITC-CD44 (clone IM7), FITC-CD62L (clone DREG-
56), PE/Cy5-CD4 (clone OKT4) and PE/Cy5-CD8 (clone RPA-T8). Appropriate isotype control antibodies were used to exclude nonspecific binding. Foxp3 intracellular staining was done with PE anti-human Foxp3 Flow Kit (Biolegend, clone 206D) according to the manufacturer's protocol. Apoptosis was determined by staining of cells with Annexin V (BD Pharmingen).

\section{Proliferation assay}

FITC BrdU Flow Kit (BD Pharmingen) was used in proliferation assays. T cells were also labeled with CFSE by incubation at $5 \times 10^{7}$ cells/mL in $5 \mu \mathrm{M}$ CFSE/HBSS for $5 \mathrm{~min}$ at room temperature. Cells were then added with an equal volume of FBS, followed by three washes in FBS-containing HBSS.

\section{Mixed lymphocyte reaction (MLR)}

Blood samples were diluted two-fold with PBS and layered onto Ficoll-Hypaque. Each tube was centrifuged at $400 \mathrm{~g}$ for $30 \mathrm{~min}$ and the lymphocytes at the interface were collected. These cells were washed once with RPMI 1640 medium containing $100 \mathrm{U} / \mathrm{ml}$ penicillin, $100 \mu \mathrm{g} / \mathrm{ml}$ streptomycin, and $2 \mathrm{mM}$ L-glutamine. They were then resuspended at $10^{7}$ cells $/ \mathrm{ml}$ in the same medium containing $10 \%$ heat inactivated FBS. Allogeneic stimulating cells were irradiated in a cesium irradiator to a total dose of $5,000 \mathrm{rad}$, to abolish their capacity to proliferate. Cultures were set up in flat-bottomed 24-well plates and $3 \times 10^{6}$ responder cells were mixed with $2 \times 10^{6}$ irradiated stimulators in $2 \mathrm{~mL}$. Cultures, set up in triplicates, were incubated for 8 days at $37^{\circ} \mathrm{C}$. Control cells cultured with medium containing low dose IL-2 $(20 \mathrm{U} / \mathrm{mL})$ in order to maintain T cell viability during a 3-day culture. No IL-2 or anti-CD3 Ab was used in MLR samples. Some cultures were pulsed with $10 \mu \mathrm{M}$ BrdU (BD Pharmingen).

\section{Statistical analysis}

Statistical comparisons between groups were made using the Student $t$ test with $P<0.0 .5$ being statistically significant.

\section{Results and discussion \\ Activation of T cells induces expression of CD25 and Foxp3 associated with effector and memory phenotype differentiation}

PBMC were stimulated with bryostatin- 1 ( $5 \mathrm{nM})$ and ionomycin $(1 \mu \mathrm{M})(\mathrm{B} / \mathrm{I})$ in the presence of $80 \mathrm{U} / \mathrm{mL}$ of IL-2 (Peprotech) for $16 \mathrm{~h}$. B/I activation mimic intracellular signals that result in $\mathrm{T}$ cell activation by increasing protein kinase $\mathrm{C}$ activity and intracellular calcium, respectively [18-20]. Cells were washed three times and cultured at $10^{6}$ cells/mL in complete medium with $40 \mathrm{U} / \mathrm{mL}$ IL-2 (Peprotech) for 3 days and expression of Foxp3 was determined using flow cytometry analysis. Expression of FoxP3 was also determined on freshly isolated $\mathrm{T}$ cells on day 0 . As 
shown in Fig. 1A (top panel), presence of IL-2 alone for 3 days did not markedly increase expression of Foxp3 or CD25 above baseline levels on day 0 (Fig. 1C). The B/I activation, however, induced Foxp3 and CD25 expression in CD4+ and CD8+ T cells (Fig. 1A, middle panel). Upon $\mathrm{B} / \mathrm{I}$ activation, CD4+CD25+Foxp3+ T cells were increased from $1 \%$ to $23 \%(P=0.016)$ and CD $8+C D 25+$ Foxp $3+\mathrm{T}$ cells were increased from $0.6 \%$ to $9 \%(P=0.013)$. Extension of culture in the presence of IL-2 for 6 days without any further stimulation retained CD4+CD25+Foxp $3+\mathrm{T}$ cells above the baseline levels in unactivated T cells $(1 \%$ vs. $7 \% ; P=0.031$ ) whereas CD $8+C D 25+F o x p 3+$ T cells dropped to baseline levels $(0.6 \%)$. These results suggest that activation-induced expression of Foxp3 in $\mathrm{CD} 4+\mathrm{CD} 25+\mathrm{T}$ cells is more stable than that in
CD8+CD25+ T cells. Absolute number of T cells increased 3 and 6 days after the B/I stimulation and expansion in the presence of IL-2 (Fig. 1B). Activation of T cells by means of anti-CD3/CD28 Abs for 3 days produced similar results as for $\mathrm{B} / \mathrm{I}$ activation by increasing CD4+CD25+FoxP3+ T cells from $0.4 \%$ to $8.7 \%$ (Fig. 1C). Phenotype analyses of T cells revealed CD44+ effector and CD44+CD62L+ memory phenotypes prior to and 6 days after the $\mathrm{B} / \mathrm{I}$ activation (Fig. 1D, top panel). While effector $\mathrm{CD} 4+$ and $\mathrm{CD} 8+\mathrm{T}$ cells were reduced after activation ( $18 \%$ to $9 \%$ and $21 \%$ to $13 \%$, respectively), memory CD4+ and CD8+ T cells were increased ( $82 \%$ to $91 \%$ and $79 \%$ to $87 \%$, respectively). Upon B/I activation, CD4+ T cells showed a 6 -fold increases of FoxP3 expression in CD44+, CD62L+ phenotypes (CD44+: $2.6 \%$ to $15 \%$;
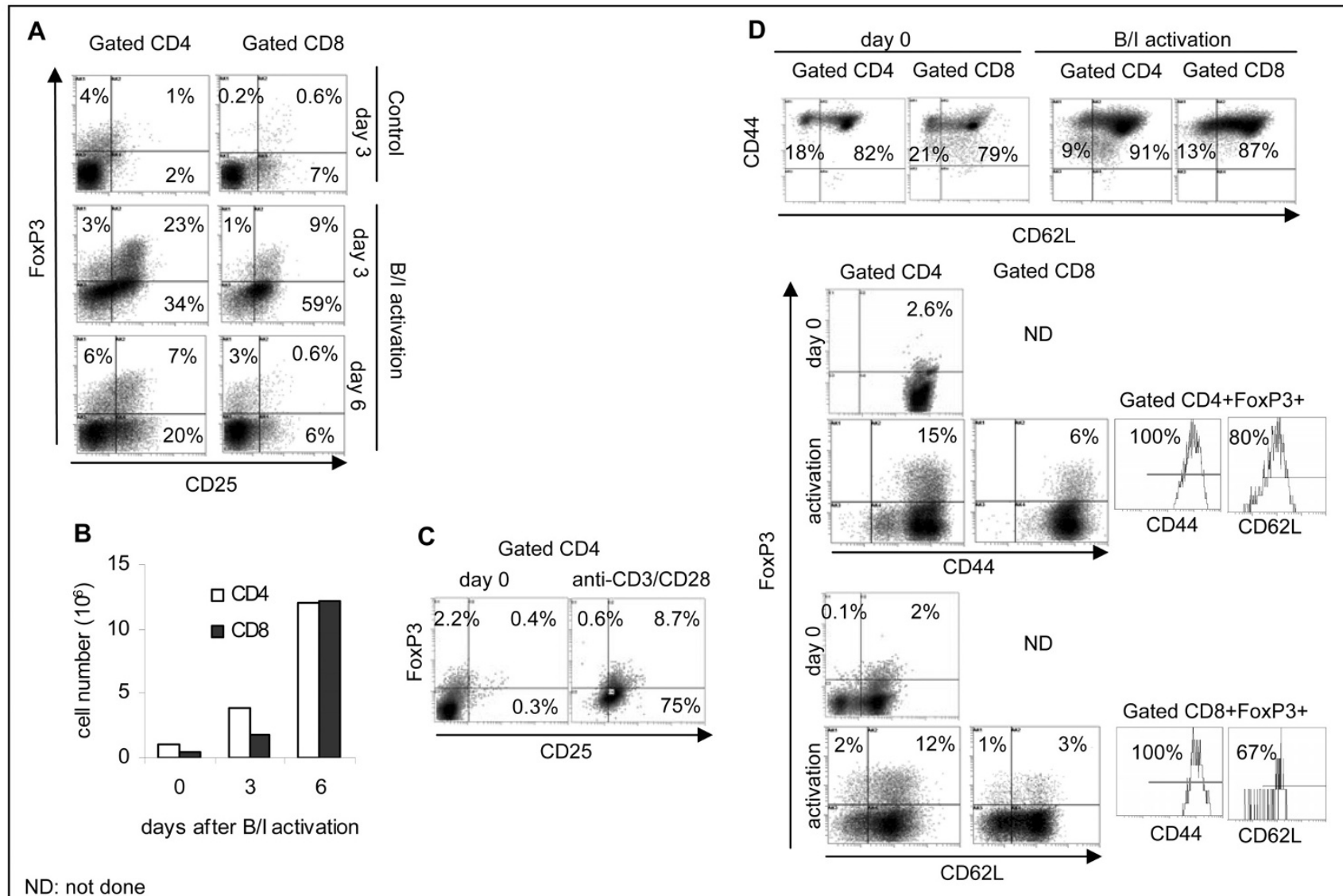

ND: not done

\section{Figure I}

Foxp3 expression following $\mathbf{T}$ cell activation. T cells were isolated from healthy volunteers and split into two groups. Control group remained unactivated and cultured in the presence of IL-2 for 3 days (A; top panel) and another group was activated with $B / I$ for $16 \mathrm{~h}$ and cultured in the presence of IL-2 for 3 days (A; middle panel) or 6 days (A; bottom panel). Absolute numbers of CD4+ and CD8+ T cells on pooled samples were determined on days 0,3 , and 6 post-culture by flow cytometry analysis (B). Expression of FoxP3 and CD25 were determined in freshly isolated CD4+ T cells (day 0) and after a 3-day stimulation with anti-CD3/CD28 Abs (C). Freshly isolated and B/l-activated $T$ cells were subjected to flow cytometry to determine T cell phenotypes (D; top panel); Foxp3+ effector and memory T cells were determined in gated CD4+Foxp3+ cells or gated CD8+Foxp3+ cells (D; bottom panel). Representative data are shown from two donors in duplicate experiments. 
A

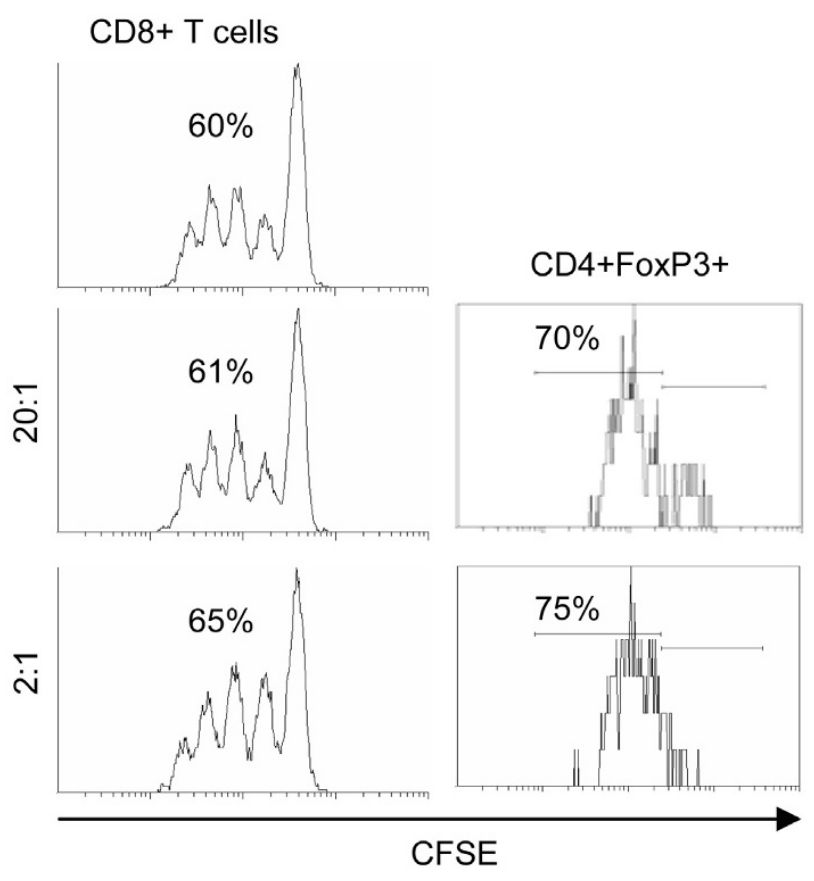

B

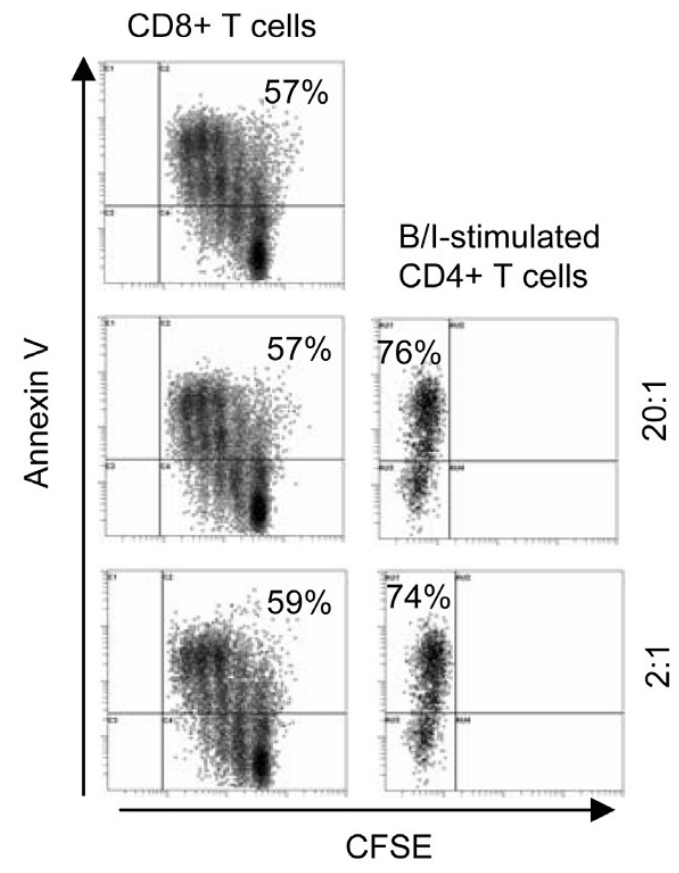

Figure 2
CD62L+: $2 \%$ to $12 \%$ ). In addition, both CD4+ and CD8+ $\mathrm{T}$ cells showed FoxP3 3 high expression following activation compared to FoxP3 $3^{\text {low }}$ expression on day 0 (Fig. 1D, middle and bottom panels). All CD4+Foxp3+ T cells expressed CD44 among which 80\% also expressed CD62L (Fig. 1D, middle panel, far right). These data show that $20 \%$ of CD $4+$ Foxp $3+$ T cells are effector and $80 \%$ are memory phenotypes. A similar phenotypic trend was detected for CD8+Foxp3+ T cells, showing 100\% CD44+ of which $67 \%$ were CD62L+ T cells (Fig. 1D, bottom panel, far right). These results show that $33 \%$ of CD8+Foxp3+ T cells are effector and 67\% are memory phenotypes. Data presented in Figs. 1A-D suggest that increased expression of FoxP3high in effector T cells was due to the cell differentiation rather than cell proliferation, because relative percent of CD44+CD62L- effector T cells decreased after B/I activation. Similar mechanism may exist in memory $\mathrm{T}$ cells because of the expression of FoxP $3^{\text {high }}$ after activation compared to FoxP3 $3^{\text {low }}$ on day 0.

\section{Activation-induced FoxP3 expression in CD4+ T cells fails to convey regulatory function in vitro}

T cells were labeled with CFSE and stimulated with antiCD3 $(1 \mathrm{ug} / \mathrm{ml})$ and anti-CD28 $(1 \mathrm{ug} / \mathrm{ml})$ Abs in the presence or absence of the B/I-activated CD4+CD25+FoxP3+ $\mathrm{T}$ cells (2:1 and 20:1 responder:suppressor ratios) for 3 days. Flow cytometry analysis showed similar rates of proliferation of gated CD $8+\mathrm{T}$ cells in the absence or presence of inducible FoxP3+ T cells (Fig. 2A, 60\% vs. 61\% and $65 \%$ ). The CD3/CD28 activation also induced FoxP3 expression in responder $\mathrm{CD} 4+\mathrm{T}$ cells. Gated CD4+FpxP3+ T cells also showed 70-75\% proliferation upon activation (Fig. 2A). Analysis of $\mathrm{T}$ cell apoptosis revealed similar rates of apoptosis in responder $T$ cells in the absence or presence of CD4+FoxP3+ T cells (Fig. 2B, $57 \%$ vs. 57 and 59\%). Majority of the B/I-activated CD4+FoxP3+ T cells (74-76\%) were found to be apoptotic during anti-CD3/CD28 activation in co-culture with responder T cells.

\section{Figure 2}

$\mathbf{T}$ cell proliferation in the presence of inducible CD4+FoxP3+ T cells. To perform a co-culture suppression assay, responder $T$ cells were labeled with CFSE and cultured in the absence or presence of different ratios of inducible FoxP3+ T cells (20:I and 2:I) for 3 days in the presence of anti-CD3/CD28 Abs. Gated CD8+ T cells showed CFSE dilution (A, left panel). Responder CD4+ $T$ cells that expressed FoxP3 due to a 3-day activation were also gated and analyzed for CFSE dilution (A, right panel). Cells obtained from a co-culture suppression assay (A, left panel) were also stained for Annexin $\mathrm{V}$ in order to determine apoptosis in responder CD8+ T cells (B, left panel) and the $B / I-$ activated $C D 4+F o x P 3+T$ cells ( $B$, right panel). 
A
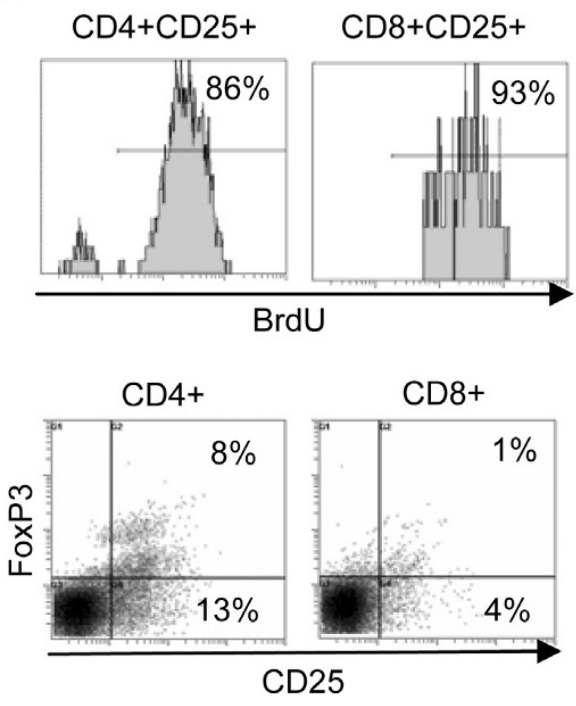

B

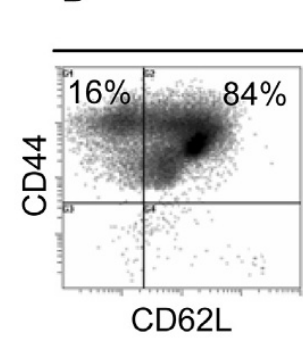

Gated CD4+

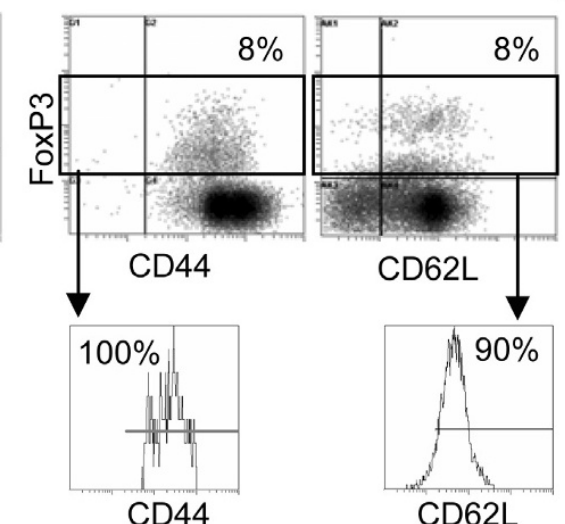

Gated CD8+

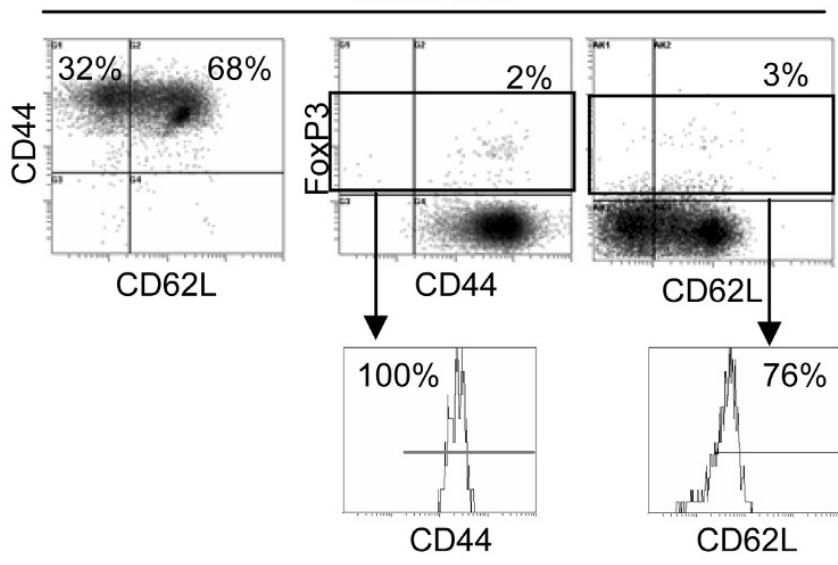

Figure 3

Foxp3 expression following allogeneic MLR. Cells were analyzed by flow cytometry after an 8-day MLR. BrdU incorporation was determined on gated $C D 4+C D 25+$ or $C D 8+C D 25+T$ cells $(A$; top panel). Gated $C D 4+$ or $C D 8+T$ cells were analyzed for the detection of CD25+Foxp3+ cells (A; bottom panel). Gated CD4+ T cells (B; top panel) or CD8+ T cells (B; bottom panel) were analyzed for the expression of CD44, CD62L, Foxp3. The CD44+ and CD62L+ T cells were determined by gating on CD4+Foxp3+ or CD8+Foxp3+ T cells. Representative data are shown from two donors in duplicate experiments.

Allogeneic activation of $T$ cells during $M L R$ induces Foxp3 expression in CD4+CD25+ T cells associated with effectorl memory phenotype

We performed an 8-day allogenic MLR to determine whether induction of Foxp3 expression in T cells was stable during MLR and whether such an induced Foxp3+ expression might inhibit $\mathrm{T}$ cell proliferation. Responder and stimulator cells were obtained from different healthy donors. Stimulator cells were irradiated (5000 rad) and cultured with responder cells for 8 days in the presence of $10 \mu \mathrm{M}$ BrdU (BD Pharmingen). Cells were then stained with relevant Abs and subjected to flow cytometry analysis. As shown in Fig. 3A (top panel) $86 \%$ of CD4+CD25+
T cells and 93\% of CD8+CD25+ T cells showed BrdU incorporation as a result of cell proliferation. No proliferation was detected in the responder or stimulator cells alone (data not shown). Such allogenic proliferation took place in the presence of an activation-induced Foxp3 expression in CD4+ T cells such that $8 \%$ of CD4+ T cells were CD25+Foxp3+ (Fig. 3A, bottom panel). CD8+CD25+ T cells, on the other hand, did not show stable expression of Foxp3. These results are consistent with our observation in Fig. 1 showing that expression of Foxp3 in CD4+ T cells is more stable than that in CD8+ T cells 6-8 days following $\mathrm{T}$ cell activation. In previous reports, suppressive assays in vitro were conducted in the 
presence of high ratios of CD4+CD25+ T cells (Tregs) to responder cells, to determine the suppressive function on $T$ cell activation and proliferation. Such artificial increases in the ratio of $\mathrm{CD} 4+\mathrm{CD} 25+\mathrm{T}$ cells to responder cells would reduce in vivo validity of the observation. The frequency of CD4+CD25+Foxp3+ T cells induced during MLR was $8 \%$ which is considered to be within the physiologically relevant range as reported by other groups [2124]. Frequency of naturally occurring Tregs in mouse is also around this range, yet having regulatory effects for the inhibition of autoimmunity. If Foxp3 expressing CD4+ T cells had any regulatory function, it should have inhibited cell proliferation during the culture in vitro. Similar to B/Iinduced $\mathrm{T}$ cell activation, $\mathrm{T}$ cell phenotypes in a MLR included CD44+ effector (16\%) and CD44+CD62L+ memory T cells (84\%) (Fig. 3B). Again, all CD4+Foxp3+ T cells expressed CD44 among which 90\% also expressed CD62L (Fig. 2B). These data show that 10\% of CD4+Foxp3+ T cells are effector and 90\% are memory phenotypes. A similar phenotypic trend was detected for CD8+Foxp3+ T cells, showing 100\% CD44+ of which $76 \%$ were CD62L+ T cells. These results show that $24 \%$ of CD8+Foxp3+ $\mathrm{T}$ cells are effector and $76 \%$ are memory phenotypes. Lack of regulatory function in these Foxp3+ T cells may be because of their effector/memory phenotype since it has been reported that expression of Foxp3 in human memory $\mathrm{T}$ cells resulted in diminished suppressor activity [25]. In addition, Treg type 1 (Tr1) cells confer suppressor function in the absence of FoxP3 expression [26]. Given the role of Foxp3 as master regulator of Treg lineage commitment and maintenance in mouse [27], it does not seem to have such bona fide regulatory function for Treg lineage commitment in human $\mathrm{T}$ cells.

\section{Conclusion}

In conclusion, the present study shows that Foxp3 expression is not a reliable marker for human Tregs. T cell activation, CD4+ T cells in particular, is associated with the expression of Foxp3 in effector/memory $\mathrm{T}$ cells without detectable regulatory function when present at physiologically relevant ratios.

\section{Abbreviations}

PBMC: peripheral blood mononuclear cells; AICD: activation induced cell death; MLR: mixed lymphocyte reaction; $\mathrm{T}$ regs: regulatory $\mathrm{T}$ cells.

\section{Competing interests}

The authors declare that they have no competing interests.

\section{Authors' contributions}

MK performed B/I activation of $\mathrm{T}$ cells, flow cytometry, MLR, and BrdU proliferation assays; MG performed flow cytometry; LG performed B/I activation of T cells; KG participated in study design; HDB participated in study design and manuscript preparation; FMM participated in study design and data analysis; MHM designed the experiments, analyzed data, and prepared the manuscript.

All authors read and approved the final manuscript.

\section{Acknowledgements}

This work was supported by NIH ROI CA 04757 grant (M. H. Manjili) and Massey Cancer Center Pilot Project Program, 646564. We gratefully acknowledge the support of VCU Massey Cancer Centre and the Commonwealth Foundation for Cancer Research.

\section{References}

I. Brunkow ME, Jeffery EW, Hjerrild KA, Paeper B, Clark LB, Yasayko SA, Wilkinson JE, Galas D, Ziegler SF, Ramsdell F: Disruption of a new forkhead/winged-helix protein, scurfin, results in the fatal lymphoproliferative disorder of the scurfy mouse. Nat Genet 200I, 27:68-73.

2. Fontenot JD, Gavin MA, Rudensky AY: Foxp3 programs the development and function of CD4+CD25+ regulatory $T$ cells. Nat Immunol 2003, 4:330-336.

3. Wildin RS, Ramsdell F, Peake J, Faravelli F, Casanova JL, Buist N, LevyLahad E, Mazzella M, Goulet O, Perroni L, Bricarelli FD, Byrne G, McEuen M, Proll S, Appleby M, Brunkow ME: X-linked neonatal diabetes mellitus, enteropathy and endocrinopathy syndrome is the human equivalent of mouse scurfy. Nat Genet 200I, 27:18-20.

4. Chatila TA, Blaeser F, Ho N, Lederman HM, Voulgaropoulos C, Helms C, Bowcock AM: JM2, encoding a fork head-related protein, is mutated in $\mathrm{X}$-linked autoimmunity-allergic disregulation syndrome. J Clin Invest 2000, 106:R75-R8I.

5. Walker MR, Kasprowicz DJ, Gersuk VH, Benard A, Van Landeghen M, Buckner JH, Ziegler SF: Induction of Foxp3 and acquisition of $T$ regulatory activity by stimulated human CD4+CD25-T cells. J Clin Invest 2003, I I 2: I437- I 443.

6. Morgan ME, van Bilsen JH, Bakker AM, Heemskerk B, Schilham MW, Hartgers FC, Elferink BG, Zanden $L$ van der, de Vries RR, Huizinga TW, Ottenhoff TH, Toes RE: Expression of FOXP3 mRNA is not confined to CD4+CD25+ T regulatory cells in humans. Hum Immunol 2005, 66: 13-20.

7. Roncador G, Brown PJ, Maestre L, Hue S, Martínez-Torrecuadrada JL, Ling KL, Pratap S, Toms C, Fox BC, Cerundolo V, Powrie F, Banham $\mathrm{AH}$ : Analysis of FOXP3 protein expression in human CD4+CD25+ regulatory $T$ cells at the single-cell level. Eur J Immunol 2005, 35:168I-169|.

8. Gavin MA, Torgerson TR, Houston E, DeRoos P, Ho WY, Stray-Pedersen A, Ocheltree EL, Greenberg PD, Ochs HD, Rudensky AY: Single-cell analysis of normal and FOXP3-mutant human $T$ cells: FOXP3 expression without regulatory $T$ cell development. Proc Natl Acad Sci USA 2006, 103:6659-6664.

9. Pillai $\mathrm{V}$, Ortega SB, Wang CK, Karandikar NJ: Transient regulatory T-cells: A state attained by all activated human T-cells. Clin Immunol 2007, 1 23:18-29.

10. Wang J, loan-Facsinay A, Voort El van der, Huizinga TW, Toes RE: Transient expression of FOXP3 in human activated nonregulatory CD4+ T cells. Eur J Immunol 2007, 37:129-138.

II. Allan SE, Crome SQ, Crellin NK, Passerini L, Steiner TS, Bacchetta R, Roncarolo MG, Levings MK: Activation-induced FOXP3 in human $\mathrm{T}$ effector cells does not suppress proliferation or cytokine production. Int Immunol 2007, 19:345-354.

12. Tran DQ, Ramsey H, Shevach EM: Induction of FOXP3 expression in naive human CD4+FOXP3 T cells by $\mathrm{T}$-cell receptor stimulation is transforming growth factor-beta dependent but does not confer a regulatory phenotype. Blood 2007, I I 0:2983-2990.

13. Michaëlsson J, Mold JE, McCune JM, Nixon DF: Regulation of T cell responses in the developing human fetus. J Immunol 2006, 176:574I-5748.

14. Hueman MT, Stojadinovic A, Storrer CE, Foley RJ, Gurney JM, Shriver $\mathrm{CD}$, Ponniah S, Peoples GE: Levels of circulating regulatory CD4+CD25+ $T$ cells are decreased in breast cancer patients 
after vaccination with a HER2/neu peptide (E75) and GMCSF vaccine. Breast Cancer Res Treat 2006, 98:17-29.

15. Okita R, Saeki T, Takashima S, Yamaguchi Y, Toge T: CD4+CD25+ regulatory $T$ cells in the peripheral blood of patients with breast cancer and non-small cell lung cancer. Oncol Rep 2005, | 4: I269-1273.

16. Mold JE, Michaëlsson J, Burt TD, Muench MO, Beckerman KP, Busch MP, Lee TH, Nixon DF, McCune JM: Maternal alloantigens promote the development of tolerogenic fetal regulatory $\mathrm{T}$ cells in utero. Science 2008, 322:1562-1565.

17. Morales JK, Kmieciak M, Graham L, Feldmesser M, Bear HD, Manjili MH: Adoptive transfer of HER2/neu-specific T cells expanded with alternating gamma chain cytokines mediate tumor regression when combined with the depletion of myeloidderived suppressor cells. Cancer Immunol Immunother 2009, 58:94I-953.

18. Cantrell $D: \mathbf{T}$ cell antigen receptor signal transduction pathways. Annu Rev Immunol 1996, I 4:259-274.

19. Chatila T, Silverman L, Miller R, Geha R: Mechanisms of T cell activation by the calcium ionophore ionomycin. J Immunol 1989, 143:1283-1289.

20. Bear HD, Roberts J, Cornell D, Tombes MB, Kyle B: Adoptive immunotherapy of cancer with pharmacologically activated lymph node lymphocytes: a pilot clinical trial. Cancer Immunol Immunother 200I, 50:269-274.

21. Toulza F, Nosaka K, Takiguchi M, Pagliuca A, Mitsuya H, Tanaka Y, Taylor GP, Bangham CR: Foxp3(+) regulatory $T$ cells are distinct from leukaemia cells in HTLV-I associated adult T-cell leukaemia. Int ] Cancer 2009, I 25:2375-2382.

22. Card CM, McLaren PJ, Wachihi C, Kimani J, Plummer FA, Fowke KR: Decreased immune activation in resistance to HIV-I infection is associated with an elevated frequency of CD4(+)CD25(+)FOXP3(+) regulatory T cells. J Infect Dis 2009, 199:1318-1322.

23. Feyler S, von Lilienfeld-Toal M, Jarmin S, Marles L, Rawstron A, Ashcroft AJ, Owen RG, Selby PJ, Cook G: CD4(+)CD25(+)Foxp3(+) regulatory $T$ cells are increased whilst CD3(+)CD4(-)CD8()alphabetaTCR(+) Double Negative $T$ cells are decreased in the peripheral blood of patients with multiple myeloma which correlates with disease burden. Br J Haematol 2009, 1 44:686-695.

24. $\mathrm{Bi} X$, Suzuki $Y$, Gatanaga $\mathrm{H}$, Oka S: High frequency and proliferation of CD4+ FOXP3+ Treg in HIV-I-infected patients with low CD4 counts. Eur J Immunol 2009, 39:30I-309.

25. Oswald-Richter K, Grill SM, Shariat N, Leelawong M, Sundrud MS Haas DW, Unutmaz D: HIV infection of naturally occurring and genetically reprogrammed human regulatory T-cells. PLOS Biol 2004, 2:El 98.

26. Roncarolo MG, Gregori S: Is FOXP3 a bona fide marker for human regulatory T cells? Eur J Immunol 2008, 38:925-927.

27. Josefowicz SZ, Rudensky A: Control of regulatory T cell lineage commitment and maintenance. Immunity 2009, 30:616-625. http://www.translational-medicine.com/content/7/1/89

Publish with Biomed Central and every scientist can read your work free of charge

"BioMed Central will be the most significant development for disseminating the results of biomedical research in our lifetime."

Sir Paul Nurse, Cancer Research UK

Your research papers will be:

- available free of charge to the entire biomedical community

- peer reviewed and published immediately upon acceptance

- cited in PubMed and archived on PubMed Central

- yours - you keep the copyright

Submit your manuscript here:

http://www.biomedcentral.com/info/publishing_adv.asp
BioMedcentral 